\title{
PERTUMBUHAN BIBIT KELAPA SAWIT DI PRE NURSERY DENGAN PEMBERIAN PUPUK ORGANIK CAIR (KULIT PISANG) DAN PUPUK NPK
}

\author{
The Growth of Oil Palm Seedlings in Pre Nursery with Addition of Liquid Organic \\ Fertilizer (Banana Peels) and NPK Fertilizer
}

\author{
Titin Setyorini*1, Retni Mardu Hartati ${ }^{1}$, Agung Lesmana Damanik ${ }^{2}$ \\ ${ }^{1}$ Program Studi Agroteknologi, Fakultas Pertanian Institut Pertanian STIPER, Yogyakarta \\ ${ }^{2}$ Program Studi Agroteknologi, Fakultas Pertanian Institut Pertanian STIPER, Yogyakarta \\ e-mail: *titin@instiperjogja.ac.id
}

\begin{abstract}
ABSTRAK
Ketersediaan tanah subur sebagai media tanam di pembibitan kelapa sawit semakin terbatas. Pemberian pupuk organik maupun anorganik pada media tanam untuk meningkatkan kandungan unsur hara sangat dibutuhkan oleh tanaman. Tujuan penelitian ini yaitu untuk mengetahui pertumbuhan bibit kelapa sawit di pre nursery dengan pemberian pupuk organik cair kulit pisang dan pupuk NPK. Penelitian dilaksanakan di Maguwoharjo, Depok, Sleman, Yogyakarta. Rancangan penelitian yang digunakan adalah rancangan faktorial (dua faktor) yang disusun dalam Rancangan Acak Lengkap. Faktor I adalah konsentrasi pupuk organik cair (POC) kulit pisang yang terdiri dari 4 aras yaitu: $\mathrm{K} 0=0 \%, \mathrm{~K} 1=10 \%, \mathrm{~K} 2=20 \%$, dan $\mathrm{K} 3=30 \%$. Faktor II adalah dosis pupuk NPK yang terdiri dari 4 aras yaitu: D0 $=0 \mathrm{~g} /$ polibag, D1 $=1,25 \mathrm{~g} /$ polibag, D2 $=2,5 \mathrm{~g} /$ polibag, dan D3 $=3,75 \mathrm{~g} /$ polibag. Data hasil pengamatan dianalisis dengan analysis of variance (ANOVA) dan Duncan's Multiple Range Test (DMRT) pada jenjang nyata 5\%. Hasil penelitian memperlihatkan terjadi interaksi nyata antara pemberian POC kulit pisang dan NPK terhadap parameter tinggi tanaman, diameter batang, berat segar tajuk, berat kering akar. Kombinasi perlakuan terbaik adalah konsentrasi POC kulit pisang $10 \%$ dan dosis pupuk NPK $1.25 \mathrm{~g} /$ tanaman.
\end{abstract}

Kata kunci : Bibit kelapa sawit, NPK, pre nursery, POC kulit pisang.

\section{ABSTRACT}

The availability of fertile soil as a growing medium in oil palm nurseries is increasingly limited. The addition of organic and inorganic fertilizers in the growing medium to increase nutrient content is needed by plants. This study aimed to determine the growth response of oil palm seedlings in the pre-nursery with addition of banana peels liquid organic fertilizer and NPK fertilizer. The research was conducted in Maguwoharjo, Depok, Sleman, Yogyakarta. Completely Randomized Design (CRD) factorial consisting of two factors was applied as experimental design. The first factor was the concentration of banana peels liquid organic fertilizer consisting of 4 levels, namely: $K O=0 \%, K 1=10 \%, K 2=20 \%$ and $K 3=30 \%$. The second factor was NPK dosage consisting of 4 levely; $D 0=0 \mathrm{~g} /$ polybag, D1 $=1.25 \mathrm{~g} /$ polybag, $D 2=2.5 \mathrm{~g} /$ polybag and D3 = $3.75 \mathrm{~g} /$ polybag. Analysis of variance (ANOVA) and Duncan's Multiple Range Test (DMRT), both with significance level of 5\%, were then used to find out whether significant differences among treatments, were existed. The result showed that there were interactions between treatments in plant height, stem diameter, shoot fresh weight, and 
root dry weight. The best combination of treatments was $10 \%$ liquid organic fertilizer concentration of banana peel and 1.25g/plant NPK fertilizer dosage.

Keywords: Oil palm seedling, pre-nursery, liquid organic fertilizer (banana peels), NPK

\section{PENDAHULUAN}

Kelapa sawit adalah komoditas perkebunan yang menjadi salah satu sumber devisa perekonomian nasional. Luas perkebunan kelapa sawit pada tahun 2008 adalah 7.363.847 ha dan pada tahun 2016 luasnya sudah mencapai 11.914.499 ha (Dirjenbun, 2016).

Perluasan perkebunan kelapa sawit yang cenderung meningkat tersebut memerlukan kecukupan bibit yang berkualitas dalam jumlah banyak. Bibit yang berkualitas diperoleh melalui kegiatan pemeliharaan yang baik. Faktor utamanya ialah jenis dan kualitas benih serta media tanam yang baik yang mampu menyediakan kebutuhan dasar bagi bibit untuk tumbuh dan berkembang. Pertumbuhan bibit yang baik akan menentukan pertumbuhan dan produksi tanaman kelapa sawit selanjutnya di lapangan (Pahan, 2011).

Ketersediaan tanah subur saat ini untuk media pembibitan sangat terbatas. Rendahnya ketersediaan unsur hara dapat menjadi faktor penghambat di pembibitan. Untuk meningkatkan kandungan unsur hara, pupuk sangat dibutuhkan oleh tanaman. Penggolongan pupuk menurut sumber bahan yang digunakan adalah pupuk organik dan anorganik. Pupuk organik berasal dari bahan organik atau mahluk hidup yang telah mati. Bahan organik tersebut akan mengalami dekomposisi dengan bantuan mikroorganisme sehingga sifat-sifatnya akan berubah. Bentuk pupuk organik dapat berupa padat ataupun cair. Pupuk organik padat adalah pupuk organik yang secara fisik berbentuk padat, sedangkan pupuk organik cair yaitu pupuk yang bentuknya cair atau larutan. Kelebihan penggunaan pupuk cair adalah pemberiannya dapat lebih merata dan kepekatan pupuknya dapat diatur sesuai kebutuhan.

Kulit pisang dapat diolah menjadi pupuk organik cair karena mengandung beberapa unsur hara antara lain : N, P, K, Ca, Mg, Na, Zn yang masing masing unsurnya berperan dalam pertumbuhan dan perkembangan tanaman sehingga dapat meningkatkan produktivitas tanaman (Suryoko, 2011). Penelitian terkait penggunaan kulit pisang sebagai pupuk organik cair telah dilakukan oleh Rambitan (2013), Nasution et al. (2014) pada tanaman sawi, Machrodania et al. (2015) pada tanaman kedelai dan Sari (2016) pada tanaman bayam. Sedangkan penelitian penggunaan kulit pisang sebagai pupuk organik cair di tanaman perkebunan terutama tanaman kelapa sawit belum banyak dilakukan sehingga perlu dilakukan penelitian penggunaan kulit pisang sebagai pupuk organik cair untuk mengetahui pengaruhnya terhadap pertumbuhan bibit kelapa sawit terutama di pre nursery.

Selain pupuk organik cair ada juga pupuk anorganik. Pupuk anorganik adalah pupuk yang dibuat oleh industri pupuk dengan meramu bahan-bahan kimia. Pupuk kimia berdasarkan unsur hara yang dikandungnya dibedakan menjadi dua yaitu pupuk tunggal dan pupuk majemuk. Pupuk tunggal merupakan pupuk yang mengandung hanya satu jenis unsur hara (contohnya unsur hara $\mathrm{N}$ atau $\mathrm{P}$ atau $\mathrm{K}$ saja), sedangkan pupuk majemuk merupakan pupuk yang mengandung lebih dari satu unsur hara (contohnya NPK). Penelitian terkait penggunaan pupuk 
NPK juga sudah dilakukan oleh Ramadhaini et al. (2014) dan Adnan (2015) pada bibit kelapa sawit di main nursery serta Sinulingga et al. (2015) pada bibit kelapa sawit di pre nursery.

Tujuan penelitian ini yaitu untuk mengetahui respon pertumbuhan bibit kelapa sawit di pre nursery terhadap pemberian pupuk organik cair kulit pisang dan pupuk NPK.

\section{METODE PENELITIAN}

Penelitian dilaksanakan pada bulan Februari - Mei 2018 di kebun petani desa Maguwoharjo, Depok, Sleman, Yogyakarta. Alat-alat yang digunakan dalam penelitian adalah timbangan digital, cangkul, ayakan, gelas ukur, ember, meteran, kertas label, penggaris, kamera dan peralatan tulis. Bahan yang digunakan antara lain kecambah kelapa sawit varietas Simalungun, pupuk organik cair kulit pisang, pupuk NPK 16:16:16, dan polibag ukuran 18 x 18 $\mathrm{cm}$.

Penelitian menggunakan metode percobaan dengan rancangan faktorial (dua faktor) yang disusun dalam Rancangan Acak Lengkap. Faktor I adalah konsentrasi pupuk organik cair kulit pisang yang terdiri dari 4 aras yaitu: $\mathrm{K} 0=0 \%, \mathrm{~K} 1=10 \%, \mathrm{~K} 2=20 \%$, dan $\mathrm{K} 3=30 \%$. Faktor II adalah dosis pupuk NPK yang terdiri dari 4 aras yaitu: D0 = 0g/polibag, D1 = 1,25g/polibag, D2 $=2,5 \mathrm{~g} /$ polibag, dan D3 $=3,75 \mathrm{~g} /$ polibag. Kombinasi perlakuan dari kedua faktor adalah $4 \mathrm{x}$ 4=16. Masing-masing kombinasi perlakuan diulang sebanyak tiga kali.

Pupuk organik cair kulit pisang yang sudah difermentasi diaplikasikan dengan cara mencampurkan pupuk ke dalam air dengan konsentrasi berbeda sesuai dengan perlakuan. Pupuk organik cair yang diberikan sebanyak $100 \mathrm{ml}$ untuk setiap aplikasi. Pupuk organik cair diaplikasikan dengan cara disiramkan ke media tanam. Aplikasi pupuk organik cair dilakukan setiap minggu genap yaitu 4, 6, 8 dan 10 Minggu Setelah Tanam (MST). Pupuk NPK diberikan dengan dosis sesuai perlakuan. Pupuk NPK diaplikasikan dengan cara dibenamkan ke dalam tanah. Aplikasi pupuk NPK dilakukan setiap minggu ganjil yaitu 5, 7, 9, 11 MST.

Parameter pengamatan adalah tinggi tanaman, jumlah daun, luas daun, diameter batang, berat segar tajuk, berat kering tajuk, panjang akar, jumlah akar, berat segar akar dan berat kering akar. Data hasil pengamatan dianalisis dengan sidik ragam (ANOVA) pada jenjang nyata 5\%. Apabila dalam analisis sidik ragam terdapat perlakuan yang berbeda nyata, maka dilanjutkan dengan Duncan's Multiple Range Test (DMRT) pada jenjang nyata 5\%.

\section{HASIL DAN PEMBAHASAN}

Hasil penelitian menunjukkan bahwa respon pertumbuhan bibit kelapa sawit di pre nursery terhadap pemberian pupuk organik cair (POC) kulit pisang dan pupuk NPK terdapat interaksi nyata pada parameter tinggi tanaman (Tabel 1), diameter batang (Tabel 2), berat segar tajuk (Tabel 3), dan berat kering akar (Tabel 4). Hal ini menunjukan bahwa pertumbuhan bibit kelapa sawit terutama pada parameter tinggi tanaman, berat seger tajuk, diameter batang dan berat kering akar dipengaruhi oleh hasil kerjasama antara perlakuan pemberian POC kulit pisang dan pupuk NPK. 
Tabel 1. Tinggi bibit kelapa sawit $(\mathrm{cm})$ pada pemberian POC kulit pisang dan pupuk NPK

\begin{tabular}{|c|c|c|c|c|}
\hline \multirow{2}{*}{ Konsentrasi POC } & \multicolumn{4}{|c|}{ Dosis Pupuk NPK } \\
\hline & $\mathbf{0} \mathbf{g}$ & $1,25 \mathrm{~g}$ & $2,50 \mathrm{~g}$ & $3,75 \mathrm{~g}$ \\
\hline $0 \%$ & $16.00 \mathrm{e}$ & 20.67 abcd & 20.33 abcd & $19.67 \mathrm{bcd}$ \\
\hline $10 \%$ & $19.00 \mathrm{~cd}$ & $21.00 \mathrm{abc}$ & $19.00 \mathrm{~cd}$ & $19.33 \mathrm{bcd}$ \\
\hline $20 \%$ & $20.00 \mathrm{bcd}$ & $18.67 \mathrm{~cd}$ & $22.67 \mathrm{a}$ & $20.00 \mathrm{bcd}$ \\
\hline $30 \%$ & $18.67 \mathrm{~cd}$ & $18.33 \mathrm{~d}$ & $21.67 \mathrm{ab}$ & $19.00 \mathrm{~cd}$ \\
\hline
\end{tabular}

Keterangan : Angka rata-rata yang diikuti oleh huruf yang sama menunjukkan berbeda tidak nyata berdasarkan uji DMRT pada taraf 5\%.

Tabel 1 memperlihatkan bahwa pemberian POC kulit pisang dan pupuk NPK saling mempengaruhi terhadap tinggi tanaman kelapa sawit di pembibitan pre nursery. Tinggi tanaman terbaik yaitu pada kombinasi konsentrasi POC 20\% dan dosis pupuk NPK 2,50g. Kombinasi konsentrasi POC 0\% dan dosis pupuk NPK 0g (kontrol) menunjukkan tinggi tanaman terendah. Tinggi tanaman pada kombinasi konsentrasi POC 20\% dan dosis pupuk NPK 2,50g tidak berbeda nyata dengan tinggi tanaman pada kombinasi konsentrasi konsentrasi POC $10 \%$ dan dosis pupuk $1.25 \mathrm{~g}$.

Tabel 2. Diameter batang (mm) pada pemberian POC kulit pisang dan pupuk NPK

\begin{tabular}{ccccc}
\hline \multirow{2}{*}{ Konsentrasi POC } & \multicolumn{4}{c}{ Dosis Pupuk NPK } \\
& $\mathbf{0 ~ g}$ & $\mathbf{1 . 2 5} \mathbf{g}$ & $\mathbf{2 . 5 0} \mathbf{g}$ & $\mathbf{3 . 7 5} \mathbf{~ g}$ \\
\hline $\mathbf{0} \%$ & $6.00 \mathrm{c}$ & $6.33 \mathrm{bc}$ & $6.67 \mathrm{bc}$ & $6.33 \mathrm{bc}$ \\
$\mathbf{1 0} \%$ & $6.00 \mathrm{c}$ & $7.67 \mathrm{a}$ & $6.00 \mathrm{c}$ & $6.00 \mathrm{c}$ \\
$\mathbf{2 0} \%$ & $6.00 \mathrm{c}$ & $6.00 \mathrm{c}$ & $6.00 \mathrm{c}$ & $6.33 \mathrm{bc}$ \\
$\mathbf{3 0} \%$ & $6.00 \mathrm{c}$ & $7.00 \mathrm{ab}$ & $6.00 \mathrm{c}$ & $6.00 \mathrm{c}$ \\
\hline
\end{tabular}

Keterangan: Angka rata-rata yang diikuti oleh huruf yang sama menunjukkan berbeda tidak nyata berdasarkan uji DMRT pada taraf 5\%

Pada Tabel 2 terlihat bahwa pemberian POC kulit pisang dan pupuk NPK saling mempengaruhi terhadap diameter batang kelapa sawit di pembibitan pre nursery. Diameter batang terbaik yaitu pada kombinasi konsentrasi POC $10 \%$ dan dosis pupuk NPK 1.25g. Diameter batang terendah yaitu pada kombinasi konsentrasi POC $0 \%$ dan dosis pupuk NPK $0 \mathrm{~g}$ (kontrol).

Tabel 3. Berat segar tajuk (g) pada pemberian POC kulit pisang dan pupuk NPK

\begin{tabular}{ccccc} 
Konsentrasi POC & \multicolumn{4}{c}{ Dosis Pupuk NPK } \\
& $\mathbf{0 ~ g}$ & $\mathbf{1 , 2 5} \mathbf{g}$ & $\mathbf{2 , 5 0} \mathbf{g}$ & $\mathbf{3 , 7 5} \mathbf{g}$ \\
\hline $\mathbf{0} \%$ & $1.82 \mathrm{~d}$ & $2.93 \mathrm{abc}$ & $3.13 \mathrm{ab}$ & $2.71 \mathrm{abcd}$ \\
$\mathbf{1 0} \%$ & $2.50 \mathrm{abcd}$ & $3.34 \mathrm{a}$ & $2.19 \mathrm{bcd}$ & $1.90 \mathrm{~cd}$ \\
$\mathbf{2 0} \%$ & $2.79 \mathrm{abcd}$ & $2.29 \mathrm{abcd}$ & $2.94 \mathrm{abc}$ & $2.35 \mathrm{abcd}$ \\
$\mathbf{3 0} \%$ & $1.91 \mathrm{~cd}$ & $2.62 \mathrm{abcd}$ & $2.56 \mathrm{abcd}$ & $2.93 \mathrm{abc}$ \\
\hline
\end{tabular}

Keterangan: Angka rata-rata yang diikuti oleh huruf yang sama menunjukkan berbeda tidak nyata berdasarkan uji DMRT pada taraf 5\% 
Tabel 3 menunjukkan bahwa pemberian POC kulit pisang dan pupuk NPK saling mempengaruhi terhadap berat segar tajuk bibit kelapa sawit di pembibitan pre nursery. Berat segar tajuk terbaik yaitu pada kombinasi konsentrasi POC $10 \%$ dan dosis pupuk NPK 1.25g. Berat segar tajuk terendah yaitu pada kombinasi kosentrasi POC 0\% dan dosis pupuk NPK 0g (kontrol).

Tabel 4. Berat kering akar (g) pada pemberian POC kulit pisang dan pupuk NPK

\begin{tabular}{ccccc}
\hline \multirow{2}{*}{ Konsentrasi POC } & $\mathbf{0} \mathbf{g}$ & $\mathbf{1 , 2 5} \mathbf{g}$ & $\mathbf{2 , 5 0} \mathbf{g}$ & $\mathbf{3 , 7 5} \mathbf{~ g}$ \\
\hline $\mathbf{0} \%$ & $0.22 \mathrm{~b}$ & $0.36 \mathrm{a}$ & $0.26 \mathrm{ab}$ & $0.21 \mathrm{~b}$ \\
$\mathbf{1 0} \%$ & $0.21 \mathrm{~b}$ & $0.28 \mathrm{ab}$ & $0.25 \mathrm{ab}$ & $0.21 \mathrm{~b}$ \\
$\mathbf{2 0} \%$ & $0.30 \mathrm{ab}$ & $0.23 \mathrm{~b}$ & $0.28 \mathrm{ab}$ & $0.22 \mathrm{~b}$ \\
$\mathbf{3 0} \%$ & $0.23 \mathrm{~b}$ & $0.23 \mathrm{~b}$ & $0.30 \mathrm{ab}$ & $0.36 \mathrm{a}$ \\
\hline
\end{tabular}

Keterangan: Angka rata-rata yang diikuti oleh huruf yang sama menunjukkan berbeda tidak nyata berdasarkan uji DMRT pada taraf 5\%

Tabel 4 menyajikan hasil bahwa pemberian POC kulit pisang dan pupuk NPK saling mempengaruhi terhadap berat kering akar bibit kelapa sawit di pembibitan pre nursery. Berat kering akar terbaik yaitu pada kombinasi konsentrasi POC 0\% dan dosis pupuk NPK 1.25g serta kombinasi konsentrasi POC 30\% dan dosis pupuk NPK 3.75g. Kombinasi konsentrasi POC 10\% dan dosis pupuk NPK 0g (kontrol) menghasilkan berat kering akar terendah. Berat kering akar pada kombinasi konsentrasi POC 0\% dan dosis pupuk NPK 1.25g serta kombinasi konsentrasi POC $30 \%$ dan dosis pupuk NPK 3.75g tidak berbeda nyata dengan berat kering akar pada kombinasi konsentrasi POC $10 \%$ dan dosis pupuk NPK $1.25 \mathrm{~g}$.

Hasil penelitian tersebut menunjukkan bahwa penggunaan pupuk organik (POC kulit pisang) bersamaan dengan pupuk anorganik (NPK) mempengaruhi beberapa parameter pertumbuhan tanaman bibit kelapa sawit seperti tinggi tanaman, diameter batang, berat segar tajuk dan berat kering akar dengan sangat baik. Hal ini diduga karena nutrisi atau unsur hara yang terkandung di kedua macam pupuk tersebut dapat saling melengkapi satu sama lain. Hasil analisis terhadap kandungan unsur hara makro pada POC (kulit pisang) adalah N-total $0.02 \%$, $\mathrm{P}_{2} \mathrm{O}_{5}$-total $0.05 \%$ dan $\mathrm{K}_{2} \mathrm{O}$-total $0.33 \%$ (Hasil analisis pupuk dari BPTP Yogyakarta). Menurut Suryoko (2011), unsur hara makro dan mikro yang dikandung dalam POC kulit pisang yaitu N, $\mathrm{P}, \mathrm{K}, \mathrm{Ca}, \mathrm{Mg}, \mathrm{Na}$, dan $\mathrm{Zn}$ yang masing-masing unsurnya dapat mendukung pertumbuhan dan perkembangan tanaman yang dapat mempengaruhi peningkatan produktivitas tanaman. Manurung (2011) juga melaporkan bahwa hasil analisis kandungan unsur hara yang terdapat pada POC pisang kepok antara lain: C-organik $0.55 \%, \mathrm{C} / \mathrm{N} 3.06 \%, \mathrm{~N}$-total $0.18 \%, \mathrm{P}_{2} \mathrm{O}_{5} 0.043 \%$, $\mathrm{K}_{2} \mathrm{O} 1.113 \%$, dan $\mathrm{pH} 4,5$.

Jika dilihat dari hasil analisis, unsur hara makro (N, P, dan $\mathrm{K}$ ) yang terkandung dalam POC kulit pisang masih terbilang cukup rendah. Akan tetapi pemberian POC kulit pisang yang dikombinasikan dengan pupuk NPK dapat mengurangi dosis anjuran pupuk NPK yang biasanya digunakan pada pembibitan kelapa sawit di pre nursery. Hasil penelitian memperlihatkan bahwa pemberian POC kulit pisang dengan konsentrasi $10 \%$ dan dosis NPK $1.25 \mathrm{~g} /$ tanaman menunjukkan hasil terbaik pada empat parameter pertumbuhan tanaman. Beberapa penelitian 
menunjukkan bahwa dosis NPK di pembibitan pre nursery yang memberikan pertumbuhan paling baik adalah sekitar $2 \mathrm{~g} /$ tanaman. Sinulingga et al. (2015) menyatakan bahwa pemberian pupuk NPK dengan dosis $2.25 \mathrm{~g} /$ bibit cendrung menunjukkan pertumbuhan lebih baik. Hal ini sejalan dengan hasil penelitian Nazari (2008) yang menunjukkan bahwa dosis pupuk NPK 2 g/tanaman menunjukkan pertumbuhan tanaman terbaik yang dilihat dari semua parameter pertumbuhan, dimana dosis tersebut lebih rendah dari dosis anjuran yaitu 2,5 g/tanaman. Dengan demikian, hasil penelitian ini menunjukkan bahwa aplikasi POC kulit pisang yang dikombinasikan dengan pupuk NPK dapat menurunkan hampir setengah dari dosis pupuk NPK yang diberikan atau dianjurkan.

POC kulit pisang dan pupuk NPK yang diberikan baik secara bersamaan atau terpisah menunjukkan hasil yang baik pada pertumbuhan dan hasil beberapa tanaman. Hal ini sesuai dengan pendapat Rambitan (2013) yang mengatakan bahwa pupuk organik cair dari kulit pisang kepok dapat berpengaruh terhadap pertumbuhan dan hasil tanaman kacang tanah, yaitu berpengaruh meningkatkan pertumbuhan tinggi batang, jumlah daun dan berat basah polong tanaman kacang tanah varietas gajah. Nasution et al., (2014) mengatakan bahwa aplikasi pupuk organik padat dan cair dari kulit pisang kepok mempengaruhi parameter tinggi tanaman sawi. Pupuk NPK berpengaruh terhadap pertumbuhan tanaman diduga karena adanya unsur hara essensial seperti N, P, dan K yang terkandung didalamnya dan jumlahnya cukup utuk memenuhi kebutuhan nutrisi tanaman. Namun apabila pupuk NPK diberikan dalam jumlah yang berlebihan dapat menyebabkan pertumbuhan tanaman terhambat. Hal ini sesuai dengan pernyataan Lubis (2008) yang menyatakan bahwa aplikasi pupuk NPK di bibit kelapa sawit memberikan pengaruh baik terhadap pertumbuhan tanaman, namun jika diberikan dalam jumlah berlebihan akan menghambat pertumbuhan.

Unsur hara $\mathrm{N}$ secara umum berperan dalam merangsang pertumbuhan vegetatif tanaman, salah satunya adalah tinggi tanaman. Unsur hara $\mathrm{P}$ mempengaruhi proses pembelahan sel tanaman untuk pembentukan organ tanaman. Disamping itu, unsur hara P juga sangat diperlukan untuk pertumbuhan akar selama tahap awal pertumbuhan tanaman. Unsur hara $\mathrm{K}$ merangsang titik-titik tumbuh tanaman. Pengaplikasian POC kulit pisang dan NPK secara bersama-sama mampu meningkatkan pertumbuhan tinggi tanaman, diameter batang yang berdampak pada peningkatan berat segar tanaman. Pupuk organik yang dikombinasikan dengan pupuk anorganik juga dapat berdampak pada pertumbuhan akar. Pada penelitian ini, kedua kombinasi pupuk tersebut mampu meningkatkan berat kering akar tanaman.

Hasil penelitian menunjukkan bahwa respon pertumbuhan bibit kelapa sawit di pre nursery dengan aplikasi POC kulit pisang dan pupuk NPK tidak terdapat interaksi nyata terhadap parameter jumlah daun, luas daun, berat kering tajuk, panjang akar, jumlah akar, dan berat segar akar (Tabel 5 dan Tabel 6). Kedua perlakuan tersebut secara terpisah juga tidak memberikan pengaruh meningkatkan parameter jumlah daun, luas daun, berat kering tajuk, panjang akar, jumlah akar, dan berat segar akar. 
Tabel 5. Jumlah daun, luas daun, berat kering tajuk, panjang akar, jumlah akar, dan berat segar akar pada perlakuan pemberian POC kulit pisang.

\begin{tabular}{lcccc}
\hline \multirow{2}{*}{\multicolumn{1}{c}{ Parameter }} & \multicolumn{4}{c}{ Konsentrasi POC } \\
\cline { 2 - 5 } & $0 \%$ & $10 \%$ & $20 \%$ & $30 \%$ \\
\hline Jumlah daun (helai) & $3.75 \mathrm{a}$ & $3.83 \mathrm{a}$ & $4.08 \mathrm{a}$ & $3.83 \mathrm{a}$ \\
Luas daun $\left(\mathrm{cm}^{2}\right)$ & $56.26 \mathrm{a}$ & $46.02 \mathrm{a}$ & $49.96 \mathrm{a}$ & $45.79 \mathrm{a}$ \\
Berat kering tajuk $(\mathrm{g})$ & $0.61 \mathrm{a}$ & $0.60 \mathrm{a}$ & $0.64 \mathrm{a}$ & $0.69 \mathrm{a}$ \\
Panjang akar $(\mathrm{g})$ & $17.16 \mathrm{a}$ & $16.00 \mathrm{a}$ & $19.32 \mathrm{a}$ & $18.84 \mathrm{a}$ \\
Jumlah akar & $3.00 \mathrm{a}$ & $3.08 \mathrm{a}$ & $3.24 \mathrm{a}$ & $2.33 \mathrm{a}$ \\
Berat segar akar $(\mathrm{g})$ & $0.94 \mathrm{a}$ & $0.91 \mathrm{a}$ & $0.97 \mathrm{a}$ & $0.91 \mathrm{a}$ \\
\hline
\end{tabular}

Keterangan : Angka rata-rata yang diikuti oleh huruf yang sama pada baris yang sama menunjukkan tidak beda nyata berdasarkan uji DMRT pada taraf $5 \%$.

Tabel 6. Jumlah daun, luas daun, berat kering tajuk, panjang akar, jumlah akar, dan berat segar akar pada pemberian pupuk NPK.

\begin{tabular}{lcccc}
\hline \multirow{2}{*}{\multicolumn{1}{c}{ Parameter }} & \multicolumn{4}{c}{ Dosis Pupuk NPK } \\
\cline { 2 - 5 } & $0 \mathrm{~g}$ & $1.25 \mathrm{~g}$ & $2.50 \mathrm{~g}$ & $3.75 \mathrm{~g}$ \\
\hline Jumlah daun (helai) & $3.75 \mathrm{p}$ & $4.00 \mathrm{p}$ & $4.00 \mathrm{p}$ & $3.75 \mathrm{p}$ \\
Luas daun $\left(\mathrm{cm}^{2}\right)$ & $44.88 \mathrm{p}$ & $49.23 \mathrm{p}$ & $56.01 \mathrm{p}$ & $47.91 \mathrm{p}$ \\
Berat kering tajuk $(\mathrm{g})$ & $0.59 \mathrm{p}$ & $0.68 \mathrm{p}$ & $0.72 \mathrm{p}$ & $0.62 \mathrm{p}$ \\
Panjang akar $(\mathrm{cm})$ & $16.49 \mathrm{p}$ & $18.74 \mathrm{p}$ & $18.91 \mathrm{p}$ & $17.16 \mathrm{p}$ \\
Jumlah akar & $2.91 \mathrm{p}$ & $2.91 \mathrm{p}$ & $3.00 \mathrm{p}$ & $2.83 \mathrm{p}$ \\
Berat segar akar $(\mathrm{g})$ & $0.73 \mathrm{p}$ & $1.01 \mathrm{p}$ & $1.09 \mathrm{p}$ & $0.94 \mathrm{p}$ \\
\hline
\end{tabular}

Keterangan : Angka rata-rata yang diikuti oleh huruf yang sama pada baris yang sama menunjukkan tidak beda nyata berdasarkan uji DMRT pada taraf $5 \%$.

Hasil tersebut diduga karena rendahnya unsur hara yang terdapat dalam POC kulit pisang. Dugaan tersebut didukung oleh hasil analisis POC kulit pisang yang telah dilakukan di laboratorium Balai Pengkajian Teknologi Pertanian Yogyakarta. Hasil analisis tersebut menunjukkan bahwa POC kulit pisang mengandung unsur $\mathrm{N}$ total $0.02 \%, \mathrm{P}_{2} \mathrm{O}_{5}$ total $0.05 \%$, dan $\mathrm{K}_{2} \mathrm{O}$ total $0.33 \%$. Kandungan unsur hara makro yang masih rendah inilah yang diduga belum memberikan pengaruh yang berbeda terhadap parameter pertumbuhaan tanaman apabila diaplikasikan secara terpisah dengan pupuk NPK. Dugaan lainya yang menyebabkan tidak pengaruh nyata pada parameter tersebut yaitu rendahnya dosis yang diberikan pada tanaman sehingga belum mampu secara nyata meningkatkan pertumbuhan tanaman. Di samping itu, penelitian yang singkat hanya sekitar empat bulan juga bisa mempengaruhi hasil penelitian. Pupuk organik merupakan pupuk yang bersifat slow release, sehingga nutrisi yang terkandung dalam POC kulit pisang belum secara maksimal diserap oleh tanaman untuk proses pertumbuhan tanaman. Jenis tanah yang digunakan yaitu tanah regosol juga dapat mempengaruhi hasil penelitian tersebut. Hal ini diduga tanah regosol yang bersifat porus tidak dapat secara maksimal menahan POC kulit pisang yang diberikan pada tanaman karena pupuk tersebut diaplikasi dalam bentuk cair. Namun demikian, konsentrasi POC $20 \%$ menunjukkan nilai rata-rata tertinggi pada lima parameter pertumbuhan tanaman (Tabel 5). 
Disamping itu pemberian pupuk NPK secara terpisah dengan dosis berbeda juga belum memberikan pengaruh berbeda pada pertumbuhan bibit kelapa sawit. Hal ini diduga pupuk NPK yang diberikan pada bulan kedua setelah tanam belum mampu secara nyata mempengaruhi pertumbuhan tanaman. Pertumbuhan bibit kelapa sawit pada awalnya sangat dipengaruhi oleh ketersediaan cadangan makanan (endosperm) yang terdapat di biji. Nazari (2008) menyatakan bahwa meningkatnya pertumbuhan tanaman dapat disebabkan oleh ketersediaan cadangan makanan (endosperm) yang terdapat dalam biji pada dua bulan pertama penanaman dan penambahan pupuk NPK pada bulan ketiga mampu menyediakan unsur hara yang cukup bagi tanaman. Namun demikian, dosis pupuk NPK $2.5 \mathrm{~g} /$ tanaman (dosis anjuran) menunjukkan nilai rata-rata tertinggi pada enam parameter pertumbuhan tanaman (Tabel 6).

Secara keseluruhan pertumbuhan bibit kelapa sawit di pre nursery belum dipengaruhi oleh aplikasi POC kulit pisang dan pupuk NPK. Hal ini diduga karena bibit kelapa sawit masih pada masa pertumbuhan, sehingga komponen-komponen parameter yang diamati pada masing-masing perlakuan belum konsisten menunjukkan perbedaan nyata. Namun demikian, pemberian POC kulit pisang dan pupuk NPK memberikan pengaruh nyata terhadap berat kering akar sehingga apabila diaplikasikan di pembibitan kelapa sawit dapat mempengaruhi pertumbuhan akar

menjadi lebih baik. Akar merupakan organ tanaman yang berperan dalam mendapatkan unsur hara, air dan oksigen yang sangat diperlukan untuk pertumbuhan tanaman. Dengan demikian, apabila pemberian POC kulit pisang dan pupuk NPK dilanjutkan sampai pembibitan main nursery mungkin akan memberikan hasil yang lebih baik pada pertumbuhan bibit kelapa sawit.

\section{KESIMPULAN}

Hasil penelitian dapat disimpulkan sebagai berikut:

1. Terdapat interaksi antara pemberian POC kulit pisang dan NPK pada parameter tinggi tanaman, diameter batang, berat segar tajuk, berat kering akar. Kombinasi perlakuan terbaik adalah konsentrasi POC kulit pisang 10\% dan dosis pupuk NPK $1.25 \mathrm{~g} / \mathrm{tanaman}$.

2. Pemberian POC kulit pisang dan pupuk NPK secara terpisah belum mempengaruhi pertumbuhan bibit kelapa sawit di pre nursery yang dilihat dari parameter jumlah daun, luas daun, berat kering tajuk, panjang akar, jumlah akar, dan berat segar akar.

\section{DAFTAR PUSTAKA}

Adnan, 2015. Pengaruh Pupuk NPK dan Pupuk Organik Terhadap Pertumbuhan Bibit Kelapa Sawit (Elaeis guineensisJacq) di Main Nursery. Jurnal Agro industri Perkebunan Vol 3 No 2 .

Dirjenbun (Direktorat Jenderal Perkebunan). 2016. Statistika Perkebunan Indonesia 2015-2017 Kelapa Sawit. Jakarta (ID): Direktorat Jenderal Perkebunan, Departemen Pertanian. 69 hal.

Lubis, A. U. 2008. Kelapa Sawit (Elaeis guinensis Jacq.) di Indonesia. Edisi 2. PPKS RISPA.

Machrodania.,Yuliana., R. Evie., 2015. Pemanfaatan Pupuk Organik Cair Berbahan Baku Kulit Pisang,Kulit Telur dan Gracillariagigas terhadap Pertumbuhan Tanaman Kedelai Var Anjasmoro. Jurnal Lentera Bio Vol 4 No 3. 
Manurung, H. 2011. Aplikasi Bioaktivator (Effective Microorganisme dan Orgadec) untuk Mempercepat Pembentukan Komposisi Limbah Kulit Pisang Kepok (Musa Paradisiaca L). Skripsi. FMIPA Biologi Universitas Mulawarman. Malang.

Nasution.J., F.Lisa., M. Meiriani. 2014. Aplikasi Pupuk Organik Padat dan Cair dari Kulit Pisang Kepok untuk Pertumbuhan dan Produksi Sawi (Brassica juncea L). Jurnal Online Agroekoteknologi. Vol.2.No3:1029-1037.

Nazari, Y.A. 2008. Respon Pertumbuhan Bibit Kelapa Sawit (Elaeis guineensis Jacq.) pada Pembibitan Awal terhadap Pupuk NPK Mutiara. Ziraa'ah Majalah Ilmiah Pertanian Vol.23 No.3 :170-184.

Pahan, Iyung. 2011. Panduan Lengkap Kelapa Sawit, Manajemen Agribisnis Kelapa Sawit dari Hulu hingga Hilir. Penerbar Swadya. Jakarta.

Ramadhaini., F.R. Sudradjat., Ade W. 2014. Optimal Dosis Pupuk Majemuk NPK dan Kalsium Pada Bibit Kelapa Sawit (Elaeis guinensisJacq) di pembibitan utama. Jurnal J.Agron. Indonesia 42 (1): 52-58.

Rambitan,V.M.M., Mirna P.S. 2013. Pengaruh Pupuk Kompos Cair Kulit Pisang Kepok (Musa paradisiacal L.) Terhadap Pertumbuhan dan Hasil Tanman Kacang Tanah (Arachis hypogaea L.) sebagai Penunjang Praktikum Fisiologi Tumbuhan. Jurnal EduBio Tropika, Vol.1,No.1

Sari, M.P. 2016. Pengaruh Pengunaan Pupuk Organik Cair Dari Limbah Kulit Buah Pisang Kepok Terhadap Pertumbuhan Tanaman Bayam (Amarathus tricolor L.). Skripsi. Universitas lampung. (tidak dipublikasikan)

Sinulingga,E.S.R., G.Jonata., T.Sabrina. 2015. Pengaruh Pemberian Pupuk Hayati Cair dan Pupuk NPK Terhada Pertumbuhan Bibit Kelapa Sawit di Pre Nursery. Jurnal Online Agroekoteknologi Vol.3,No.3.1219-1225.

Suryoko, Hary. 2011. Kiat pintar memproduksi pupuk dengan penguraian buatan sendiri. Liliy Publistier, Yogyakarta. 